\title{
Coping Strategies and Life Satisfaction among Romanian Emerging Adults during the COVID-19 Pandemic
}

\author{
Delia Ștefenel ${ }^{1, *} \mathbb{(}$, Jose-Michael Gonzalez ${ }^{2}$, Silviu Rogobete ${ }^{3}\left[\right.$ and Raluca Sassu ${ }^{4}(\mathbb{C}$ \\ 1 Faculty of Social and Humanities, Lucian Blaga University of Sibiu, 550024 Sibiu, Romania \\ 2 Department of Psychology, Sacred Heart University, Fairfield, CT 5151, USA; jmgnum1@aol.com \\ 3 Faculty of Political Science, Philosophy and Communication Sciences, West University of Timișoara, \\ 300223 Timișoara, Romania; silviu.rogobete@e-uvt.ro \\ 4 Human Behaviour and Development Research Lab, Lucian Blaga University of Sibiu, 550024 Sibiu, Romania; \\ raluca.sassu@ulbsibiu.ro \\ * Correspondence: delia.stefenel@ulbsibiu.ro
}

check for updates

Citation: Ștefenel, D.; Gonzalez, J.-M.; Rogobete, S.; Sassu, R. Coping Strategies and Life Satisfaction among Romanian Emerging Adults during the COVID-19 Pandemic. Sustainability 2022, 14, 2783. https:// doi.org/10.3390/su14052783

Academic Editor: Delia Vîrgă

Received: 31 December 2021

Accepted: 21 February 2022

Published: 26 February 2022

Publisher's Note: MDPI stays neutral with regard to jurisdictional claims in published maps and institutional affiliations.

Copyright: (C) 2022 by the authors. Licensee MDPI, Basel, Switzerland. This article is an open access article distributed under the terms and conditions of the Creative Commons Attribution (CC BY) license (https:// creativecommons.org/licenses/by/ $4.0 /)$.

\begin{abstract}
The aim of the present study was to understand coping mechanisms among Romanian youth in their response to institutional COVID-19 pandemic restrictions. Data were collected from emerging adults $(\mathrm{N}=214)$, aged $18-29$, enrolled in various fields of study throughout a public university in Romania. Adopted versions of the Coping Orientation for Problem Experiences Scale (Brief-COPE, Carver, 1997) and Satisfaction with Life Scales (SLWS) were administered to explore the impact of the specific social distancing and isolation enforced pandemic restrictions. Findings elucidate the response styles, impact of coping skills, and strategies employed by students toward their well-being during stay-at-home courses. Results indicated that Romanian emerging-adults tend to use diverse strategies, but they use more disengagement, problem-focused coping, humor, socially supportive coping or religion, rather than denial, avoidant-focused coping or substance use, when faced with unprecedented situations during the COVID-19 pandemic. We discuss these findings framed in resilience as it relates to the positive youth psychology framework.
\end{abstract}

Keywords: coping strategies; satisfaction with life; emerging adults; COVID-19; Romania

\section{Introduction}

The outbreak of the COVID-19 pandemic has put individuals' physical and mental health at risk, generating significant disruptions to normative developmental experiences, which has captured the attention of research communities and practitioners worldwide. In Romania, as around the world, teachers, counselors, and other leaders were suddenly thrust into creating an all-online world, in which the charge of preparing emerging adults in the shadow of institutionally enforced restrictions led to the unprecedented adaptation and promotion of novel strategies and life skills necessary for successful educational and employment attainment. Indeed, for today's youth, computers and phones are primary modes of communication, and many emerging adults have taken some form of stay-at-home course. However, during this difficult time, COVID-19 challenged Romanian educators and emerging adults' insights on how all-online environments impact the maintenance and development of coping skills and resilience necessary to succeed in education and life. The novel coronavirus lockdown has impacted both youth and adult populations in negative ways, on the one hand, by generating fear [1], loneliness [2], anxiety [3], prolonged sleep disorder [4], chronic and online fatigue [5], technostress due to overexposure to IT communication means [6], misinformation [7], low work engagement [8], as well as somatic pains during the stay-at-home period [9]. On the other hand, the impacts of the COVID-19 pandemic have led to several positive outcomes, mainly in the case of introducing digital learning [10], encouraging building up resilience mechanisms [11], activating different beneficial psychological resources [12], and relying on social support [13] or on differing 
coping mechanisms [14]. Specifically in the Romanian context, initial research has shown that individuals differing in age and developmental profiles proved to respond differently to the stress experiences caused by the pandemic restrictions [15-17], with a notable gap in the existent literature on the experiences of emerging adults and their coping responses.

Lately, researchers, practitioners, and scholars have been concerned with better understanding the impacts of pandemic restrictions, especially among youth and emerging adults, who are already undergoing a turbulent and confusing developmental stage in their lifespan [18]. While research on emerging adults in Romania is in an incipient phase, [19-22], coping and life satisfaction during the transition to adulthood have rarely been studied. Even less information exists on the unprecedented impact of COVID-19 restrictions on these important regulatory processes during this key developmental stage. As such, pandemic adversities may imprint deeper into mental health and psychological well-being [23,24], and this study hopes to uncover further knowledge on the skills and strategies employed by Romanian emerging adults that will inform practice concerned with providing appropriate coping tools that would enhance positive developmental outcomes for emerging adults [25].

Importance of Life Satisfaction

Positive psychology entails the scientific study of strengths and virtues that enable individuals and communities to thrive. Subjective Well-Being, which is conceptualized as multifaceted in nature, contains both affective and cognitive evaluations of one's life. Life satisfaction is suggested as an important indicator of the positive development approach [26]. Life satisfaction constitutes a distinct construct representing a cognitive and global evaluation of the quality of one's life as a whole $[27,28]$. Life satisfaction refers to a judgmental process in which individuals assess the quality of their lives on the basis of their own unique set of criteria [29]. A study conducted by [30] Garcia and Moradi (2011) found that the subjective well-being of an adolescent can be studied through the assessment of life satisfaction, the frequency of positive affect, and the frequency of negative affect. In line with this statement, our research explored the relationship between the experience of stay-at-home classes and emerging adults' perception of Life Satisfaction, and aimed to specifically examine which coping skills and strategies were predictive of adolescent well-being among Romanian emerging adults.

Conceptualization of coping

We conceptualize coping with stressful situations based on an individual's responses to disparate stressors and disruptions [31,32]. The Transactional Model of Stress proposed by Lazarus and Folkman [33] contends that a person's capacity to cope and adjust to challenges and problems is a consequence of transactions (or interactions) that occur between a person and their environment. The Self-Regulation Model of Coping [32], with roots in the Transactional Model of Stress, is concerned with an individual's dealing effectively or ineffectively with a stressful situation in corresponding to two major mechanisms of mobilizing individual resources: approach coping and avoidant coping. On the one side, strategies such as denial, substance use, venting, behavioral disengagement, self-distraction, and self-blame are considered appropriate for avoidant coping types. On the other hand, active coping, positive reframing, planning, acceptance, seeking emotional support, and seeking informational support are considered to belong to approach coping styles [32]. Religion and humor were separated, as these proved not to load on any of the second-order dimensions. Religion, for example, was reported by several scholars, as a fluid construct, loading either to avoidant coping types [34] or approach coping types [35]. In addition to the influence of the binaries of avoidant-approach [31] and of problem -emotion focus coping, [33] we also draw from the literature on coping strategies where similar dichotomic coping paradigms are presented, such as negative/disengaged versus positive/active coping [36]; adaptive (with active coping, positive reframing, use of emotional support, acceptance, religion, humor, planning, and use of instrumental support) versus maladaptive coping behaviors (with venting, denial, substance use, behavioral disengagement, selfdistraction, and self-blame) [37]; active (positive) versus passive (avoidant) coping [38]. 
Among the most commonly used self-report instruments to assess individual coping strategies is the 28 items Brief COPE [31], an abbreviated version of the initial 60-item Coping Orientation for Problem Experience (COPE) [32]. The Brief COPE is a multidimensional inventory comprising 28 items for the following 14 different types of coping tactics: self-distraction, active coping, denial, substance use, use of emotional support, use of instrumental support, behavioral disengagement, venting, positive reframing, planning, humor, acceptance, religion, self-blame.

Various versions of COPE questionnaires have been tested in various fields of clinical and medical practice and were found to have great flexibility and generalizability of application among populations exposed to different stressors, including at-risk youth and emerging adults. For example, researchers have addressed coping strategies among young populations, applying diverse versions of Brief COPE in emerging adult samples [36,39], in university or college student samples [34,40-42], and among children and adolescents [43]. However, very few studies have assessed coping behaviors during COVID-19 lockdown [44-46], and none (to the best of our knowledge) have addressed coping mechanisms in relation to positive youth development in Romania during the first wave of coronavirus restrictions.

In addition, extensive literature exists in which the factoriability of short versions of COPE was explored. For example, a two-factor model was confirmed in [47,48]; a threefactor model was found in [36,49-53]; a five-factor model was found in [54]; a six- factor model was confirmed in [55]; a seven-factor model-in [56]; an eight-factor model was found in [57]; a nine-factor model was found in [58], while an fourteen-factor structure was proposed in the brief version of COPE [31].

There is a considerable amount of literature dedicated to testing The Brief COPE Inventory in different environment and countries. The Brief COPE scale was validated in different countries, such as Chile [53], China [57,59,60], Italy [61], France [52,62,63], Malaysia [58] Mexico [56], Serbia [64], Russia [44], Spain [65], Uruguay [50], USA [66], United Arab Emirates [67]; as well as different languages and dialects-Persian [68], Tunisian Arabic [69], Urdu [70], Vietnamese [71], Brazilian and Portuguese [49].

In Romania, although the initial version of COPE was translated by the authors of [72-74], researchers have encountered difficulty in assessing its replicable factoriability [72]. The Brief COPE (28 items) has since been applied among Romanian physicians [75-77] among unemployed people [78], but the Romanian literature is still underdeveloped. Therefore, our attempt is to fill the existent gap by utilizing this measure on coping mechanisms among the Romanian emerging adults during COVID-19-enforced restrictions in their undertaking of online home coursework during lockdown.

Resilience in Positive Youth Development

Benson (1997) [79] postulated that "resilience" indicates a paradigm shift from the identification of the risk factors of an individual (i.e., a pathological view) to the identification of strengths of an individual, and the process of, capacity for, or outcome of successful adaptation despite challenging or threatening circumstances [80]. Therefore, resilience can be defined as the process of effectively mobilizing internal and external resources in adapting to or managing significant sources of stress or trauma [81]. Thus, cultivation of resilience means fostering adolescents' capacity, flexibility, and coping strategies as they face developmental changes and life stresses in order to "bounce back" from difficult life experiences and achieve positive outcomes [82]. Studies indicate that the main difference between those who adapt well despite facing risks and those who end up in maladaptation is the existence of protective factors. Additionally, optimism, perceptions of control, self-efficacy, and active coping were found to be associated with better health and well-being. 
The present study

The present study aims to examine the relationship between the experience of COVID-19 coping responses and emerging adults' perception of life satisfaction, and to specifically explore which coping responses were predictive of emerging adults' perception of life satisfaction.

Research question: What is the relation between life satisfaction and coping mechanisms among Romanian emerging adults during the COVID-19 pandemic?

\section{Materials and Methods}

\section{Participants}

A convenience sample was used, formed by 214 emerging adults, enrolled in academia $(\mathrm{M}=21.32, \mathrm{SD}=2.06)$, attending undergraduate $(90.9 \%)$ and postgraduate $(9.1 \%)$ programs of diverse specializations (social sciences, medicine, engineering, law, art and literature) at a central Romanian public university, during the early stage of the COVID-19 pandemic (Table 1).

Table 1. Sample characteristics.

\begin{tabular}{cc}
\hline & $\begin{array}{c}\text { Romanian Sample } \\
(\mathbf{N}=\mathbf{2 1 4})\end{array}$ \\
\hline Age (in years) M (SD) & $21.32(2.06)$ \\
\hline Gender (\%) females & $78.6 \%$ \\
\hline Year of Study & \\
\hline I & $40.8 \%$ \\
\hline II & $31.7 \%$ \\
\hline III & $18.3 \%$ \\
\hline IV & $2.8 \%$ \\
\hline V & $6.3 \%$ \\
\hline Working during COVID-19 lockdown? & \\
\hline Yes & $20.2 \%$ \\
\hline No & $79.8 \%$ \\
\hline
\end{tabular}

Measures and procedure

Instruments and procedure

Coping strategies. A translation of The Brief COPE [31] for lockdown settings was used to assess emerging adults' coping styles with pandemic consequences. The instrument originates from the long version of the COPE (Coping Orientation to Problems Experienced) Inventory [32,72]. The translation into Romanian of the adapted version, obtained via committee approach, consists of 28 items, rated on a 4-point Likert scale, ranging from 1 ("I have not been doing this at all") to 4 ("I have been doing this a lot"). Sample items include: "During COVID-19 pandemic, I've been blaming myself for things that happened", "I have been trying to come up with a strategy about what to do." and "I have been expressing my negative feelings". Cronbach's alpha showed good internal consistency, $\alpha=0.79$.

Life satisfaction. The Satisfaction with Life Scale (SWLS), which was proposed in $[19,83,84]$, was translated into Romanian, using a committee approach, and it measures life satisfaction among Romanian students during the COVID-19 lockdown. The answers to the SWLS items were given on a five-point Likert scale, from 1 ("never") to 5 ("always"). Sample items include: "In most ways my life is close to my ideal", "I am satisfied with my life", "If I could live my life over, I would change almost nothing". Cronbach's alpha $\alpha=0.84$. 
Socio-demographics. Students were asked to report their age, gender, university, study program, field of study, and whether they were working or not during the COVID-19 pandemic lockdown. Students completed the online questionnaire, comprising Brief COPE and SWBS items, all available in their native language, on an electronic platform, which was considered the most appropriate approach, due to physical and distancing constraints.

Participation was anonymous and voluntary, with no remuneration for participation in the study, which took place during the first wave of COVID-19 pandemic (beginning of April-end of May 2020). The paper is part of the "Resilience and Well-Being during COVID-19 Pandemic" Project, initiated by the first author at Lucian Blaga University of Sibiu, Romania $[8,15]$.

Preliminary analysis

One of the aims of the present paper was to assess emerging adults' coping strategies in the context of the COVID-19 pandemic. To this end, we first tested the theoretical structure of the applied Brief COPE instrument using Principal Components Analysis (PCA) and Varimax rotation. We employed Bartlett's Test of Sphericity, Kaiser-Meyer-Olking (KMO) seeking eigenvalues greater or equivalent to one and factor loadings, EFA (exploratory factory analysis), and CFA (confirmatory factor analysis) in SPSS v.22. In our case, KaiserMeyer-Olking (KMO) revealed a high measure of sample adequacy of 0.746 and Bartlett's Test of Sphericity showed significance with a $p$-level $<0.001$, therefore, our sample met the basic requirements for factor analysis.

The Principal Components Analysis (PCA) conducted on the Brief COPE measure displayed good factoriability among the eight-component structure, which accounted for $66.14 \%$ of total variance (from $4.12 \%$ to $18.84 \%$ per factor). In order to evaluate the theoretical foundation of the model, a number of statistics were included [83]: root mean square error of approximation (RMSEA, recommended $<0.08$ ), comparative fit index (CFI, recommended $>0.95$ ), Tucker-Lewis Index (TLI, recommended $>0.90$ ), normed fit index (NFI, recommended $>0.90)$, and significant $p$-values $(p>0.05)$. For the Brief COPE tested in our sample, the best fitting model included eight factors, with CFI value of 0.85 , NFI value of 0.75 , and TLI of 0.82 , and the RMSEA of 0.069 . In accordance with these indicators, the minimum values were achieved, with a chi-square sensitive to sample size $\left(\chi^{2}(344)=1,072,147, p<0.001\right)$. In our attempt to assess other proposed inspiring models, with a four-factor solution $[44,50,51]$, and with a two-factor solution $[37,47,48]$, the same goodness of fit statistics was verified. In the case of the four-factor model, the majority of the values were below the acceptable levels: $\mathrm{CFI}=0.670, \mathrm{NFI}=0.585, \mathrm{TLI}=0.637$, with RMSEA $=0.100,\left(\chi^{2}(322)=644,597, p<0.001\right)$. A notable poor model fit was further obtained in the case of the two-factor model: CFI $=0.453, \mathrm{NFI}=0.398, \mathrm{TLI}=0.404$, with RMSEA $=0.127,\left(\chi^{2}(349)=1,554,794, p<0.001\right)$. Therefore, at best, the eight-model fit reported moderate and marginal acceptance levels. Nevertheless, in line with prior studies and following the recommendations of the original model [31], the Brief COPE with 28 items was adapted and applied for the specific Romanian context and population, in a sample-dependent way, using prior explanatory-based models, followed by factor analysis, in order to establish the optimal fitting factor model structure for the tested sample. Our results suggest that the eight-factor model for Brief-COPE in the Romanian setting was found to be the most suitable model, sharing several similarities with previous research outcomes [57,85].

The eight factors were labelled in accordance with their constitutive factors and items, as follows: socially supportive coping, problem-focused coping, avoidant coping, denial, religion, substance use, humor, disengagement.

Factor 1, socially supportive coping, includes items related to emotional support, instrumental support, and venting.

Factor 2, problem-focused coping, comprised items describing active coping, positive framing, planning, and one item of acceptance.

Factor 3, avoidant-focused coping, included key items for behavioral disengagement and self-blame. 
Factor 4 covers the two items designed to measure denial.

Factor 5 included items relevant for religious behavior.

Factor 6 includes items measuring substance use.

Factor 7 includes items measuring humor.

Factor 8, disengagement, includes the two items of self-distraction and one item of acceptance (acceptance measured in terms of taking the situation as it comes and learning to live the situation).

\section{Results and Discussion}

In line with prior theoretical and empirical considerations presented above, the purpose of our paper was to expand the existent literature on Positive Psychology and SelfRegulation. Our study was focused on providing empirical answers regarding how life satisfaction might be associated with coping dimensions among Romanian emerging adults engaged in online academic environments resulting from the COVID-19 pandemic lockdown. Overall, our results revealed greater values for life satisfaction, along with disengagement, problem-focused coping, humor, socially supportive coping, religion factors, while lower scores surfaced (under the midpoint split) for denial, avoidant-focused coping, and substance use (Table 2).

Table 2. Descriptive Statistics for Brief COPE and Life Satisfaction for the Romanian emerging adult sample.

\begin{tabular}{cccccc}
\hline & N & Minimum & Maximum & Mean & Std. Deviation \\
\hline Disengagement & 214 & 1.33 & 4.00 & 3.1090 & 0.56183 \\
Problem-focused coping & 214 & 1.00 & 4.00 & 2.9339 & 0.55226 \\
Humor & 214 & 1.00 & 4.00 & 2.3668 & 0.88931 \\
Socially supportive coping & 214 & 1.00 & 4.00 & 2.3028 & 0.73203 \\
Religion & 214 & 1.00 & 4.00 & 2.1822 & 0.99622 \\
Denial & 214 & 1.00 & 4.00 & 1.7570 & 0.81754 \\
Avoidant-focused coping & 214 & 1.00 & 3.00 & 1.2991 & 0.44066 \\
Substance use & 214 & 1.00 & 4.00 & 1.2266 & 0.61955 \\
Life satisfaction & 214 & 1.00 & 5.00 & 3.8483 & 0.75996 \\
\hline
\end{tabular}

Pearson bivariate correlations among study variables, including general well-being and the eight Brief COPE factors were conducted to examine the relationship between the dimensions included in our study (Table 3). In line with prior studies [53], we presumed that there was a relation between coping responses and well-being, understood through the life satisfaction indicator. The correlation analysis shows that subjective well-being as a whole construct is positively enhanced under social problem-focused coping $(\mathrm{r}=0.323$, $p<0.01)$ and when religion is used $(\mathrm{r}=0.170, p<0.05)$, but negatively so under general avoidant focused coping styles $(\mathrm{r}=-0.344, p<0.01)$ and substance use $(\mathrm{r}=-0.252, p<0.01)$. No non-significant results were found when testing the link between youth life satisfaction when making use of socially supportive coping $(\mathrm{r}=0.053, \mathrm{~ns})$, denial $(\mathrm{r}=-0.032$, $\mathrm{ns})$, humor $(\mathrm{r}=0.045, \mathrm{~ns})$, and disengagement $(\mathrm{r}=0.085, \mathrm{~ns})$.

Table 3. Correlations between Subjective Well-Being and Brief COPE components.

\begin{tabular}{|c|c|c|c|c|c|c|c|c|c|}
\hline & 1 & 2 & 3 & 4 & 5 & 6 & 7 & 8 & 9 \\
\hline 1 Life satisfaction & - & & & & & & & & \\
\hline 2 Socially supportive coping & 0.053 & - & & & & & & & \\
\hline 3 Problem-focused coping & $0.323^{* *}$ & $0.313^{* *}$ & - & - & & & & & \\
\hline 4 Avoidant-focused coping & $-0.344^{* *}$ & $0.251^{* *}$ & $-0.202 * *$ & - & & & & & \\
\hline 5 Denial & -0.032 & $0.221^{* *}$ & -0.046 & $0.291^{* *}$ & - & & & & \\
\hline 6 Religion & $0.170 *$ & $0.249 * *$ & $0.248^{* *}$ & 0.068 & 0.058 & - & & & \\
\hline 7 Substance use & $-0.252^{* *}$ & 0.052 & $-0.246^{* *}$ & $0.357^{* *}$ & $0.223^{* *}$ & -0.079 & - & & \\
\hline 8 Humor & 0.045 & -0.026 & $0.150 *$ & -0.079 & 0.091 & -0.108 & 0.010 & - & \\
\hline 9 Disengagement & 0.085 & $0.283^{* *}$ & $0.389 * *$ & -0.090 & 0.095 & 0.073 & -0.105 & 0.025 & - \\
\hline
\end{tabular}

Note: ${ }^{* *} p<0.01 ;{ }^{*} p<0.05$. 
Additionally, by means of a predictive model, we assessed the significance of each of the eight components of general life satisfaction of youth during the COVID-19 pandemic $\left(R^{2}=0.183, F(173)=5.852, p<0.001\right)$. The linear regression analysis revealed that avoidant-focused coping was the strongest negative predictor of the overall life satisfaction ( $\beta=-0.300, p<0.01)$, followed by problem focused coping $(\beta=-0.214, p<0.05)$, and last, being negatively influenced by substance use $(\beta=-0.147, p<0.05)$ (Table 4$)$.Consequently, we may conclude that non-active responses, such as avoidant coping, may predispose to a negative effect on Romanian emerging adults' well-being.

Table 4. Standardised coefficient for life satisfaction predictive model.

\begin{tabular}{|c|c|c|c|c|c|}
\hline \multirow{2}{*}{ Model } & \multicolumn{2}{|c|}{ Unstandardized Coefficients } & \multirow{2}{*}{$\begin{array}{c}\text { Standardized Coefficients } \\
\text { Beta }\end{array}$} & \multirow{2}{*}{$\mathbf{t}$} & \multirow{2}{*}{ Sig. ${ }^{a}$} \\
\hline & B & Std. Error & & & \\
\hline (Constant) & 3.778 & 0.471 & & 8.016 & 0.000 \\
\hline Socially supportive coping & 0.053 & 0.082 & 0.052 & 0.645 & 0.520 \\
\hline Problem-focused coping & 0.306 & 0.120 & 0.214 & 2.561 & 0.011 \\
\hline Avoidant-focused Coping & -0.536 & 0.138 & -0.300 & -3.896 & 0.000 \\
\hline Denial & 0.053 & 0.068 & 0.058 & 0.781 & 0.436 \\
\hline Religion & 0.071 & 0.058 & 0.091 & 1.242 & 0.216 \\
\hline Substance use & -0.240 & 0.119 & -0.147 & -2.024 & 0.045 \\
\hline Humor & -0.004 & 0.061 & -0.004 & -0.061 & 0.951 \\
\hline Disengagement & -0.075 & 0.106 & -0.054 & -0.705 & 0.482 \\
\hline
\end{tabular}

${ }^{\text {a }}$ Dependent variable: Subjective well-being.

The aim of this chapter was to advance the research in an understudied emerging adult sample, by offering empirical evidence on coping responses during the COVID-19 pandemic.

Our findings emphasized an eight-factor structure model of the Brief COPE measure, in which socially supportive coping, problem-focused coping, avoidant-focused coping, denial, religion, substance use, humor, and disengagement were loaded onto the coping responding styles. Our results provide an answer in accordance with previous studies, where coping mechanisms and well-being were linked, more precisely, avoidance-type coping being associated with poor well-being [36], and adaptive coping being related to better well-being outcomes [37]. Similar results were empirically found in [53], where well-being was positively associated with the majority of adaptive coping behaviors (instrumental and emotional support, active coping, acceptance, planning, positive framing, and religion) and negatively so with maladaptive or dysfunctional coping styles (self-blaming, behavioral disengagement, venting, and substance use). In the attempt to test for gender differences, admitting the unbalanced gender distribution of the sample, female participants were reported to score higher on their general life satisfaction during COVID-19 restrictions. Such findings should be further extended, as life satisfaction was tested as self-perception and not as an internationalized outcome in any other context than in the general pandemic experience in Romania. In addition, approach-based strategies, such as socially supportive coping and problem-focused coping, were more preferred by female respondents than male ones, confirming, thus, the results of prior studies [53] on stress and coping responding styles.

We admit that future research should explore more in-depth effects, such as gender, age, external and internal affects, so as to broaden the study of coping mechanisms among different samples and stressful contexts. Despite several limitations of the current study (gender sample size, regional sampling, online data completion, study level enrollment), our findings suggest that it remains important for policy makers to encourage stakeholders to establish local and national strategies for promoting positive youth development. For example, strategies such as raising awareness and acting toward enabling quality contact and better well-being in stressful contexts should be employed. It is recommended that, as part of stay-at-home classes, students should partake in on-going training to develop 
better coping mechanisms, to be aware of expectations, and to review the alternatives and resources they may use in order to build self-confidence and solve their problems.

Certainly, cultivating resilience can promote the psychological and social development of youth and emerging adults. As such, it is key to strengthen an individual's ability to identify and utilize social support systems in their respective surroundings [84-86]. Moreover, academic leaders can benefit from preparing youth regarding informal types of social support (relational, familial, neighborhood, community, etc.), while policy makers can examine the resources and accessibility of formal support systems, such as non-formal education, alternative education programs, tutorial classes, school psychology sessions, students integrated services. The salience of protective factors (Bonding, Competence, Optimism, and Environment) is gained through experiences with informal and formal social supports across the lifespan, which have been demonstrated to have multiple positive impacts in relational experiences in fostering resilience [87-89]. Especially, in the current experience of enforced pandemic restrictions characterized by isolation and social distancing (since emerging adults have been outright disconnected, lost, or were challenged with establishing relationships), promotion of formal and informal social support is arguably the most important protective factor in promoting positive development. The results are useful for tailoring and implementing coping-based instruments in times of crisis, in order to enhance positive youth development and build up resilience mechanisms in stressful circumstances. The positive psychology framework provides a holistic perspective that promotes a successful development in several psychological, physical, and/or socio-emotional developmental domains, and includes key contexts of adolescent development, such as family, school, and community, that contribute to the understanding of several positive outcomes as associated with life satisfaction and resilience as indicators of positive youth development [83]. Research suggests that the sheer number of positive experiences youth have contribute considerably to their health and well-being, with higher likelihoods in cumulative positive experiences, regardless of the outcome that is targeted. Rather, in addition to the results of this study, specific coping responses, such as focusing more on solving a specific problem rather than using avoidance-type coping and substance use, are especially influential predictors of life satisfaction. These study findings extend knowledge on the nature of emerging adults' experiences and resources in relation to their impact on positive developmental outcomes, providing knowledge on how to foster life satisfaction in early adulthood when faced with unprecedented challenges such as COVID-19 in all-online stay-at-home education. Better independent life navigation, self-reliance, self-focus, goal setting, active coping, positive framing, and planning stand as being useful resources for emerging adults in enhancing life satisfaction, and can also have a positive impact on the existing challenges experienced by youth throughout this difficult developmental stage. Practitioners should incorporate solution-oriented mechanisms during daily remote learning, which stimulate and encourage better interaction, communication, relationships, and the well-being of students. By fostering and building up new resources and strengths, we predict an increased likelihood of a more efficient dual strategy of attempting to build more assets throughout young people's ecologies, while especially targeting the promotion of specific clusters of emerging adults' competencies to enhance life satisfaction.

Author Contributions: Conceptualization, D.S. and J.-M.G.; methodology, D.S, and J.-M.G.; software, D.S.; validation, D.S,., J.-M.G. and R.S.; formal analysis, D.S. and J.-M.G.; investigation, D.S.; resources, D.Ș. and J.-M.G.; data curation, D.Ș.; writing—original draft preparation, D.Ș., J.-M.G., S.R. and R.S.; writing-review and editing, D.S., J.-M.G., R.S. and S.R.; visualization, D.S., R.S. and S.R.; supervision, S.R. and R.S.; project administration, D.S.; funding acquisition, D.S. All authors have read and agreed to the published version of the manuscript.

Funding: Project financed by Lucian Blaga University of Sibiu \& Hasso Plattner Foundation research grants LBUS-IRG-2020-06.

Informed Consent Statement: Informed consent was obtained from all subjects involved in the study. 
Data Availability Statement: The data presented in this study are available on request from the corresponding author.

Acknowledgments: The authors would like to gratefully acknowledge the support of the project financed by Lucian Blaga University of Sibiu \& Hasso Plattner Foundation research grants LBUSIRG-2020-06.

Conflicts of Interest: The authors declare no conflict of interest. The funders had no role in the design of the study; in the collection, analyses, or interpretation of data; in the writing of the manuscript, or in the decision to publish the results.

\section{References}

1. Ahorsu, D.K.; Lin, C.Y.; Imani, V.; Saffari, M.; Griffiths, M.D.; Pakpour, A.H. The Fear of COVID-19 Scale: Development and Initial Validation. Int. J. Ment. Health Addict. 2020, 1, 1-9. [CrossRef] [PubMed]

2. Okruszek, Ł.; Aniszewska-Stańczuk, A.; Piejka, A.; Wiśniewska, M.; Żurek, K. Safe but Lonely? Loneliness, Anxiety, and Depression Symptoms and COVID-19. Front. Psychol. 2020, 11, 3222. [CrossRef] [PubMed]

3. Canestrari, C.; Bongelli, R.; Fermani, A.; Riccioni, I.; Bertolazzi, A.; Muzi, M.; Burro, R. Coronavirus Disease Stress Among Italian Healthcare Workers: The Role of Coping Humor. Front. Psychol. 2021, 11, 3962. [CrossRef]

4. Marelli, S.; Castelnuovo, A.; Somma, A.; Castronovo, V.; Mombelli, S.; Bottoni, D.; Leitner, C.; Fossati, A.; Ferini-Strambi, L. Impact of COVID-19 lockdown on sleep quality in university students and administration staff. J. Neurol. 2021, 268, 8-15. [CrossRef] [PubMed]

5. Bartoszek, A.; Walkowiak, D.; Bartoszek, A.; Kards, G. Mental Well-Being (Depression, Loneliness, Insomnia, Daily Life Fatigue) during COVID-19 Related Home-Confinement-A Study from Poland. Int. J. Environ. Res. Public Health 2020, 17, 7417. [CrossRef] [PubMed]

6. Penado Abilleira, M.; Rodicio-García, M.L.; Ríos-de Deus, M.P.; Mosquera-González, M.J. Technostress in Spanish University Teachers during the COVID-19 Pandemic. Front. Psychol. 2021, 12, 496. [CrossRef]

7. Secosan, I.; Virga, D.; Crainiceanu, Z.P.; Bratu, L.M.; Bratu, T. Infodemia: Another Enemy for Romanian Frontline Healthcare Workers to Fight during the COVID-19 Outbreak. Medicina 2020, 56, 679. [CrossRef]

8. Stefenel, D.; Balaban, M.I. Evaluarea Implicării în Muncă în timpul Pandemiei COVID-19 (Assesing Work Engagement during COVID-19 pandemic). In Abordari si Studii de Caz Relevante Privind Managementul Organizatiilor din România în Contextul Pandemiei COVID-19; Dumitrascu, D., Popa, I., Nicolescu, O., Eds.; Pro Universitaria: București, Romania, 2020; pp. $203-212$.

9. López-Valenciano, A.; Suárez-Iglesias, D.; Sanchez-Lastra, M.A.; Ayán, C. Impact of COVID-19 Pandemic on University Students' Physical Activity Levels: An Early Systematic Review. Front. Psychol. 2021, 11, 3787. [CrossRef]

10. Pokhrel, S.; Chhetri, R.A. Literature Review on Impact of COVID-19 Pandemic on Teaching and Learning. High. Educ. Future 2021, 8, 133-141. [CrossRef]

11. Zabaniotou, A. A systemic approach to resilience and ecological sustainability during the COVID-19 pandemic: Human, societal, and ecological health as a system-wide emergent property in the Anthropocene. Glob. Transit. 2020, 2, 116-126. [CrossRef]

12. Pretti, T.J.; Etmanaski, B.; Durston, A. Remote work-integrated learning experiences: Student perceptions. Int. J. Work Integr. Learn. 2020, 21, 401-414.

13. Xu, J.; Ou, J.; Luo, S.; Wang, Z.; Chang, E.; Novak, C.; Shen, J.; Zheng, S.; Wang, Y. Perceived Social Support Protects Lonely People Against COVID-19 Anxiety: A Three-Wave Longitudinal Study in China. Front. Psychol. 2021, 11, 2759. [CrossRef] [PubMed]

14. Savitsky, B.; Findling, Y.; Ereli, A.; Hendel, T. Anxiety and coping strategies among nursing students during the COVID-19 pandemic. Nurse Educ. Pract. 2020, 46, 102809. [CrossRef] [PubMed]

15. STtefenel, D.; Neagos, I. Measuring academic engagement among university students in Romania during COVID-19 pandemic. Thesis Int. Res. J. 2020, 9, 3-29.

16. Dascalu, S. The Successes and Failures of the Initial COVID-19 Pandemic Response in Romania. Front. Public Health 2020, 8, 344. [CrossRef] [PubMed]

17. Panisoara, I.O.; Lazar, I.; Panisoara, G.; Chirca, R.; Ursu, A.S. Motivation and Continuance Intention towards Online Instruction among Teachers during the COVID-19 Pandemic: The Mediating Effect of Burnout and Technostress. Int. J. Environ. Res. Public Health 2020, 17, 8002. [CrossRef] [PubMed]

18. Arnett, J.J. Emerging Adulthood: The Winding Road from the Late Teens Through the Twenties; Oxford University Press: New York, NY, USA, 2004; pp. 1-385.

19. Dimitrova, R.; Buzea, C.; Abubakar, A. Measurement Invariance of the Satisfaction with Life Scale in Roma Minority and Romanian Majority Adolescents in Romania. Psihol. Resur. Um. 2016, 14, 111-121.

20. Nelson, L.J. An examination of emerging adulthood in Romanian college students. Int. J. Behav. Dev. 2009, 33, 402-411. [CrossRef]

21. Negru, O.; Subţirică, A.; Opre, A. The dynamics of aspirations in emerging adulthood. Procedia Soc. Behav. Sci. 2011, 12, 205-210. [CrossRef]

22. Negru-Subtirica, O.; Tiganasu, A.; Dezutter, J.; Luyckx, K. A cultural take on the links between religiosity, identity, and meaning in life in religious emerging adults. Br. J. Dev. Psychol. 2017, 35, 106-126. [CrossRef] 
23. Germani, A.; Buratta, L.; Delvecchio, E.; Gizzi, G.; Mazzeschi, C. Anxiety Severity, Perceived Risk of COVID-19 and Individual Functioning in Emerging Adults Facing the Pandemic. Front. Psychol. 2020, 11, 3384. [CrossRef] [PubMed]

24. DiFonte, M.; James, C.; Michel, R.; Flannery-Schroeder, E. 51.5 COVID-19 impact on anxiety and depression among emerging adults: The role of mindfulness. J. Am. Acad. Child Adolesc. Psychiatry 2020, 59, S252. [CrossRef]

25. Scales, P.C.; Benson, P.L.; Oesterle, S.; Hill, K.G.; Hawkins, J.D.; Pashak, T.J. The dimensions of successful young adult development: A conceptual and measurement framework. Appl. Dev. Sci 2016, 20, 150-174. [CrossRef] [PubMed]

26. Park, N. Character Strengths and Positive Youth Development. Ann. Am. Acad. Political Soc. Sci. 2004, 591, 40-54. [CrossRef]

27. Diener, E.; Suh, E.M.; Lucas, R.E.; Smith, H.L. Subjective well-being: Three decades of progress. Psychol. Bull. 1999, 125, $276-302$. [CrossRef]

28. Pavot, W.; Diener, E. Review of the Satisfaction with Life Scale. Psychol. Assess. 1993, 5, 164-172. [CrossRef]

29. Shin, D.C.; Johnson, D.M. Avowed happiness as an overall assessment of the quality of life. Soc. Indic. Res. 1979, 5, 475-492. [CrossRef]

30. Garcia, D.; Moradi, S. Adolescents' Temperament and Character: A Longitudinal Study on Happiness. J. Happiness Stud. 2012, 13, 931-946. [CrossRef]

31. Carver, C.S. You want to measure coping but your protocol's too long: Consider the brief COPE. Int. J. Behav. Med. 1997, 4, 92-100. [CrossRef]

32. Carver, C.S.; Scheier, M.F.; Weintraub, J.K. Assessing coping strategies: A theoretically based approach. J. Personal. Soc. Psychol. 1989, 56, 267-283. [CrossRef]

33. Lazarus, R.S.; Folkman, S. Stress, Appraisal, and Coping; Springer: New York, NY, USA, 1984.

34. Schnider, K.R.; Elhai, J.D.; Gray, M.J. Coping style use predicts posttraumatic stress and complicated grief symptom severity among college students reporting a traumatic loss. J. Couns. Psychol. 2007, 54, 344-350. [CrossRef]

35. Krägeloh, C.U. A Systematic Review of Studies Using the Brief COPE: Religious Coping in Factor Analyses. Religions 2011, 2, 216-246. [CrossRef]

36. Cramer, R.J.; Braitman, A.; Bryson, C.N.; Long, M.M.; La Guardia, A.C. The Brief COPE: Factor Structure and Associations with Self- and Other-Directed Aggression among Emerging Adults. Eval. Health Prof. 2020, 43, 120-130. [CrossRef]

37. Meyer, G.J.; Finn, S.E.; Eyde, L.D.; Kay, G.G.; Moreland, K.L.; Dies, R.R.; Eisman, E.J.; Kubiszyn, T.W.; Reed, G.M. Psychological testing and psychological assessment: A review of evidence and issues. Am. Psychol. 2001, 56, 128-165. [CrossRef] [PubMed]

38. Bowleg, L.; Craig, M.L.; Burkholder, G. Rising and surviving: A conceptual model of active coping among Black lesbians. Cult. Divers. Ethn. Minority Psychol. 2004, 10, 229-240. [CrossRef] [PubMed]

39. Jenzer, T.; Read, J.P.; Naragon-Gainey, K.; Prince, M.A. Coping trajectories in emerging adulthood: The influence of temperament and gender. J. Personal. 2019, 87, 607-619. [CrossRef]

40. Bonneville-Roussy, A.; Evans, P.; Verner-Filion, J.; Vallerand, R.J.; Bouffard, T. Motivation and coping with the stress of assessment: Gender differences in outcomes for university students. Contemp. Educ. Psychol. 2017, 48, 28-42. [CrossRef]

41. Miyazaki, Y.; Bodenhorn, N.; Zalaquett, C.; Ng, K.M. Factorial structure of Brief COPE for international students attending U.S. colleges. Coll. Stud. J. 2008, 42, 795-806.

42. Ribeiro, J.L.P.; Rodrigues, A.P. Questões acerca do coping: A propósito do estudo de adaptação do Brief COPE. Psicol. Saúde Doenças 2004, 5, 3-15.

43. Eschenbeck, H.; Kohlmann, C.W.; Lohaus, A. Gender differences in coping strategies in children and adolescents. J. Individ. Differ. 2007, 28, 18-26. [CrossRef]

44. Voronin, I.A.; Manrique-Millones, D.; Vasin, G.M.; Millones-Rivalles, R.B.; Manrique-Pino, O.; Fernández-Ríos, N.; Marakshina, Y.A.; Lobaskova, M.M.; Symanyuk, E.E.; Pecherkina, A.A.; et al. Coping Responses during the COVID-19 Pandemic: A Cross-Cultural Comparison of Russia, Kyrgyzstan, and Peru. Psychol. Russ. State Art 2020, 13, 55-74. [CrossRef]

45. Agha, S. Mental well-being and association of the four factors coping structure model: A perspective of people living in lockdown during COVID-19. Ethics Med. Public Health 2021, 16, 100605. [CrossRef] [PubMed]

46. Yldırım, M.; Arslan, G.A. Moderated Mediation Effect of Stress-Related Growth and Meaning in Life in the Association between Coronavirus Suffering and Satisfaction with Life: Development of the Stress-Related Growth Measure. Front. Psychol. 2021, 12, 529. [CrossRef] [PubMed]

47. Tuncay, T.; Musabak, I.; Gok, D.E.; Kutlu, M. The relationship between anxiety, coping strategies and characteristics of patients with diabetes. Health Qual. Life Outcomes 2008, 6, 79. [CrossRef]

48. Moore, B.C.; Biegel, D.E.; McMahon, T.J. Maladaptive Coping as a Mediator of Family Stress. J. Soc. Work. Pract. Addict. 2011, 11, 17-39. [CrossRef]

49. Brasileiro, S.V.; Orsini, M.R.C.A.; Cavalcante, J.A.; Bartholomeu, D.; Montiel, J.M.; Costa, P.S.S.; Costa, L.R. Controversies Regarding the Psychometric Properties of the Brief COPE: The Case of the Brazilian-Portuguese Version "COPE Breve". PLoS ONE 2016, 11, e0152233. [CrossRef]

50. Reich, M.; Ball, C.D.; Remor, E. Estudio de las propiedades psicométricas del Brief COPE para una muestra de mujeres uruguayas. Av. En Psicol. Latinoam. 2015, 34, 615-636. [CrossRef]

51. Nahlen Bose, C.; Bjorling, G.; Elfstrom, M.; Persson, H.; Saboonchi, F. Assessment of Coping Strategies and Their Associations with Health Related Quality of Life in Patients with Chronic Heart Failure: The Brief COPE Restructured. Cardiol. Res. 2015, 6, 239-248. [CrossRef] 
52. Baumstarck, K.; Alessandrini, M.; Hamidou, Z.; Auquier, P.; Leroy, T.; Boyer, L. Assessment of coping: A new French four-factor structure of the brief COPE inventory. Health Qual. Life Outcomes 2017, 15, 8. [CrossRef]

53. García, F.E.; Barraza-Peña, C.G.; Wlodarczyk, A.; Alvear-Carrasco, M.; Reyes-Reyes, A. Psychometric properties of the Brief-COPE for the evaluation of coping strategies in the Chilean population. Psicol. Reflex. Crit. Rev. Semest. Dep. Psicol. UFRGS 2018, 31, 1-11. [CrossRef]

54. Mohanraj, R.; Jeyaseelan, V.; Kumar, S.; Mani, T.; Rao, D.; Murray, K.R.; Manhart, L.E. Cultural adaptation of the Brief COPE for persons living with HIV/AIDS in southern India. AIDS Behav. 2015, 19, 341-351. [CrossRef] [PubMed]

55. Su, X.Y.; Lau, J.T.; Mak, W.W.; Choi, K.C.; Feng, T.-J.; Chen, X.; Liu, C.-L.; Liu, J.; Liu, D.; Chen, L.; et al. A preliminary validation of the Brief COPE instrument for assessing coping strategies among people living with HIV in China. Infect. Dis. Poverty 2015, 4, 41. [CrossRef] [PubMed]

56. Ornelas, R.; Anahí, M.; Vite, A.; Guerrero, O.; Rosas, A.; Sánchez, J. Afrontamiento en pacientes con cáncer de mama en radioterapia: Análisis de la Escala COPE breve [coping in breast cancer patients undergoing radiotheraphy: The brief COPE scale]. Psicol. Salud 2013, 23, 55-62.

57. Barraza, C.G. Propiedades Psicométricas del Cuestionario Brief Cope 28 en Población Chilena Expuesta a Eventos Altamente Estresantes [Psychometric Properties of the Brief Cope in Chilean Population Exposed to Highly Stressful Events]. 2018, XVI Coloquio Panamericano de Investigación en Enfermería, Cuba. Available online: https:/ / coloquioenfermeria2018.sld.cu/index. php/coloquio/2018/paper/viewPaper/616 (accessed on 20 December 2021).

58. Yusoff, N.; Low, W.Y.; Yip, C.H. Reliability and validity of the Brief COPE Scale (English version) among women with breast cancer undergoing treatment of adjuvant chemotherapy: A Malaysian study. Med. J. Malays. 2010, 65, 41-44.

59. Yuan, W.; Zhang, L.; Li, B. Adapting the Brief COPE for Chinese Adolescents with Visual Impairments. J. Vis. Impair. Blind. 2017, 111, 20-32. [CrossRef]

60. Snell, D.L.; Siegert, R.J.; Hay-Smith, E.J.; Surgenor, L.J. Factor structure of the brief COPE in people with mild traumatic brain injury. J. Head Trauma Rehabil. 2011, 26, 468-477. [CrossRef]

61. Monzani, D.; Steca, P.; Greco, A.; D’Addario, M.; Cappelletti, E.; Pancani, L. The Situational Version of the Brief COPE: Dimensionality and Relationships with Goal-Related Variables. Eur. J. Psychol. 2015, 11, 295-310. [CrossRef]

62. Doron, J.; Trouillet, R.; Gana, K.; Boiché, J.; Neveu, D.; Ninot, G. Examination of the hierarchical structure of the Brief COPE in a French sample: Empirical and theoretical convergences. J. Personal. Assess. 2014, 96, 567-575. [CrossRef]

63. Muller, L.; Spitz, E. Evaluation multidimensionnelle du coping: Validation du Brief COPE sur une population française [Multidimensional assessment of coping: Validation of the Brief COPE among French population]. Encephale 2003, $29,507-518$.

64. Stanislava, J.D. Activity matters: Physical exercise and stress coping during the 2020 COVID-19 state of emergency. Psihologij 2021, 54, 307-322.

65. Moran, C.; Landero, R.; González, M. COPE-28: Un análisis psicométrico de la versión en español del brief COPE. [COPE-28: A psychometric analysis of the Spanish version of the brief COPE]. Univ. Psychol. 2010, 9, 543-552. [CrossRef]

66. Farley, T.; Galves, A.; Dickinson, L.M.; de Jesus Diaz Perez, M.J. Tress, coping, and health: A comparison of Mexican immigrants, Mexican-Americans, and non-Hispanic Whites. Immigr. Health 2005, 7, 213-220. [CrossRef] [PubMed]

67. Rahman, H.A.; Issa, W.B.; Naing, L. Psychometric properties of brief-COPE inventory among nurses. BMC Nurs. $2021,20,73$.

68. Ashktorab, T.; Baghcheghi, N.; Seyedfatemi, N.; Baghestani, A. Psychometric parameters of the Persian version of the BriefCOPE among wives of patients under hemodialysis. Med. J. Islamic Repub. Iran 2017, 31, 113-118.

69. Nawel, H.; Elisabeth, S. Adaptation and validation of the Tunisian version of the Brief COPE Scale. Eur. Health Psychol. 2015, 17, 783.

70. Nisa, A.; Siddiqui, S. Urdu Translation and Adaptation of Brief COPE Scale. Pak. J. Psychol. Res. 2020, 35, 1-21.

71. Matsumoto, S.; Yamaoka, K.; Nguyen, H.; Nguyen, D.T.; Nagai, M.; Tanuma, J.; Mizushima, D.; Nguyen, K.V.; Pham, T.N.; Oka, S. Validation of the Brief Coping Orientation to Problem Experienced (Brief COPE) inventory in people living with HIV/AIDS in Vietnam. Glob. Health Med. 2020, 2, 374-383. [CrossRef]

72. Crasovan, D.I.; Sava, F.A. Translation, Adaptation, and Validation on Romanian Population of Cope Questionnaire for Coping Mechanisms Analysis. Cogn. Brain Behav. Interdiscip. J. 2013, 17, 61-76.

73. Glăveanu, S.M. Rezistenţa la Stres-Resursă A Competenței Parentale. Rev. Psih. 2012, 58, 45-56.

74. Popescu, M.D. Agresivitatea Organizaţională-Autocontrolul emoţiilor şi strategiile de coping ale angajaţilor. Rev. Psih. 2014, 60, 119-130.

75. Popa-Velea, O.; Diaconescu, L.V.; Gheorghe, I.R.; Olariu, O.; Panaitiu, I.; Cerniţanu, M.; Goma, L.; Nicov, I.; Spinei, L. Factors Associated with Burnout in Medical Academia: An Exploratory Analysis of Romanian and Moldavian Physicians. Int. J. Environ. Res. Public Health 2019, 16, 2382. [CrossRef] [PubMed]

76. Popa-Velea, O.; Diaconescu, L.; Jidveian Popescu, M.; Truţescu, C. Resilience and active coping style: Effects on the self-reported quality of life in cancer patients. Int. J. Psychiatry Med. 2017, 52, 124-136. [CrossRef] [PubMed]

77. Popa-Velea, O.; Mihăilescu, A.I.; Diaconescu, L.V.; Gheorghe, I.R.; Ciobanu, A.M. Meaning in Life, Subjective Well-Being, Happiness and Coping at Physicians Attending Balint Groups: A Cross-Sectional Study. Int. J. Environ. Res. Public Health 2021, $18,3455$. [CrossRef] [PubMed]

78. Bordea, N.E.; Manea, M.; Pellegrini, A. Unemployment and coping with stress, anxiety, and depression. Czech J. Soc. Sci. Bus. Econ. 2017, 6, 6-14.

79. Benson, P. Developmental Assets: An Overview of Theory, Research, and Practice. Approaches Posit. Youth Dev. 2007, $33,58$. 
80. Masten, A.S.; Best, K.M.; Garmezy, N. Resilience and development: Contributions from the study of children who overcome adversity. Dev. Psychopathol. 1990, 2, 425-444. [CrossRef]

81. Windle, G. What is resilience? A review and concept analysis. Rev. Clin. Gerontol. 2011, 21, 152-169. [CrossRef]

82. Catalano, R.F.; Berglund, M.L.; Ryan, J.A.M.; Lonczak, H.S.; Hawkins, J.D. Positive Youth Development in the United States: Research Findings on Evaluations of Positive Youth Development Programs. Ann. Am. Acad. Political Soc. Sci. 2004, 591, 98-124. [CrossRef]

83. Lee, T.Y.; Cheung, C.K.; Kwong, W.M. Resilience as a positive youth development construct: A conceptual review. Sci. World J. 2012, 2012, 390450. [CrossRef]

84. Diener, E.; Emmons, R.A.; Larsen, R.J.; Griffin, S. The Satisfaction with Life Scale. J. Personal. Assess. 1985, 49, 71-75. [CrossRef]

85. Mackay, S.; Burdayron, R.; Körner, A. Factor structure of the Brief COPE in patients with melanoma. Can. J. Behav. Sci. Rev. Can. Sci. Comport. 2021, 53, 78-83. [CrossRef]

86. Hepworth, D.H.; Rooney, R.H.; Larsen, J.A. Direct Social Work Practice: Theory and Skills; Brooks/Cole-Thomson Learning: Pacific Grove, CA, USA, 2002.

87. Masten, A. Resilience in developing systems: Progress and promise as the fourth wave rises. Dev. Psychopathol. 2007, 19, 921-930. [CrossRef] [PubMed]

88. Masten, A.S.; Reed, M.J. Resilience in Development. In Handbook of Positive Psychology; Snyder, C.R., Lopez, S.J., Eds.; Oxford University Press: New York, NY, USA, 2002; pp. 117-131.

89. Hu, L.T.; Bentler, P.M. Cutoff criteria for fit indexes in covariance structure analysis: Conventional criteria versus new alternatives. Struct. Equ. Modeling 1999, 6, 1-55. [CrossRef] 